Nurkholis, Minimalisasi Kerusakan Spermatozoa Kambing Peranakan Etawah Akibat Radikal Bebas Selama Periode Cryopreservation Dengan Penambahan A Tokoferol Dari Ekstrak Limbah Edamame Dalam Skim Milk Dilution

\title{
MINIMALISASI KERUSAKAN SPERMATOZOA KAMBING PERANAKAN ETAWAH AKIBAT \\ RADIKAL BEBAS SELAMA PERIODE Cryopreservation DENGAN PENAMBAHAN A TOKOFEROL DARI EKSTRAK LIMBAH EDAMAME DALAM SKIM MILK DILUTION
}

Oleh:

\section{NURKHOLIS *)}

\begin{abstract}
ABSTRAK
Tujuan dari penelitian ini adalah untuk mengetahui tingkat keefektifan tokoferol hasil ekstrak limbah edamame dalam melindungi membran sperma dari radikal bebas, menghasilkan metoda baru dalam penyimpanan semen kambing PE, dan mampu mempertahankan kualitas sperma selama penyimpanan. Materi penelitian ini adalah pemanfaatan limbah edamame yaitu biji sortir (muki) dan kambing jantan Peranakan Etawah yang berumur \pm 12 bulan untuk ditampung semennya dengan menggunakan vagina buatan.

Hasil penelitian menunjukkan, penambahan ekstrak edamame kedalam pengencer semen tidak berpengaruh nyata $(\mathrm{P}>0,05)$ dalam mempertahankan kualitas semen (motilitas, abnormalitas, dan viabilitas) selama penyimpanan baik pada suhu kamar maupun di suhu dingin, kecuali untuk persentase abnormalitas spermatozoa pada penyimpanan suhu dingin penambahan ekstrak edamame berpengaruh nyata $(\mathrm{P}<0,05)$.

Kesimpulan dari penelitian ini adalah penambahan ekstrak edamame tidak memberikan pengaruh nyata $(\mathrm{P}>$ 0,05) dalam mempertahankan kualitas (motilitas, abnormalitas, dan viabilitas) semen kambing Peranakan Etawah selama penyimpanan pada suhu kamar dan suhu dingin $\left(3-5^{\circ} \mathrm{C}\right)$, penambahan ekstrak edamame memberikan pengaruh nyata $(\mathrm{P}<0,05)$ terhadap persentase abnormalitas spermatozoa pada penyimpanan suhu dingin, penambahan ekstrak edamame dengan dosis $0,4 \mathrm{~g} / 100 \mathrm{ml}$ memberikan hasil rerata yang lebih tinggi dibandingkan dengan dosis yang lebih rendah.
\end{abstract}

Kata kunci: ekstrak limbah edamame, pengencer, kualitas semen 


\section{PENDAHULUAN}

Keberhasilan IB (Inseminasi Buatan) dipengaruhi oleh beberapa faktor, satu diantaranya adalah kualitas bahan yang digunakan untuk pengencer semen. Pengencer semen berfungsi mempertahankan kehidupan dan daya gerak sperma selama proses penyimpanan (Toelihere, 1993).

Pengolahan semen kambing selama ini banyak menggunakan kuning telur sebagai bahan pengencer. Kuning telur mengandung zat lechitin yang digunakan sebagai pelindung membran sperma secara ekstra seluler. Lechitin kuning telur akan berubah menjadi lisolechitin dan asam lemak oleh enzim fosfolipase A yang terdapat pada semen kambing. Hasil hidrolisa lechitin kuning telur oleh enzim foslipase A bersifat racun bagi sperma dan menyebabkan koagulan semen (.Rizal dan Herdis, 2008). Tingginya asam lemak tidak jenuh dalam fosfolipid menyebabkan membrane plasma rentan akan terjadinya peroksida lipid. Peroksida lipid yang berkepanjangan akan merusak struktur matrik lipid dan menyebabkan ketidakstabilan pada membrane (Hammerstedt, 1993). Reaksi peroksidasi lipid dapat dihambat dengan penambahan antioksidan yakni suatu zat yang dapat mengikat senyawa radikal bebas (Wijaya, 1996). Berdasarkan uraian tersebut diperlukan penelitian tentang "Efektivitas $\alpha$-Tokoferol Ekstrak Limbah Edamame Sebagai Antioksidan yang Berguna dalam Mempertahankan Kualitas Spermatozoa Kambing Peranakan Etawah".

\section{Tujuan}

Mengetahui tingkat keefektifan tokoferol hasil ekstrak limbah edamame dalam melindungi membran sperma dari radikal bebas.

Berdasarkan uraian tersebut dapat diharapkan dengan penambahan ekstrak limbah edamame dalam bahan pengencer semen dapat mencegah atau menghambat terjadinya radikal bebas, sehingga kualitas semen kambing Peranakan Etawah dapat terjaga selama proses preservasi.

Materi dan Metode Penelitian

\section{Lokasi dan Waktu Penelitian}

Penelitian ini akan dilaksanakan di Laboratorium Produksi Ternak dan Laboratorium Biosain Politeknik Negeri Jember, dengan lama waktu 2 bulan.

\section{Bahan dan Alat}

\section{Bahan Penelitian}

Bahan yang digunakan dalam penelitian ini adalah limbah edamame yaitu biji sortir (muki). Biji dipisahkan dari kulit dan dikeringkan, kemudian digiling sampai halus atau berbentuk serbuk. Bahan lain yang digunakan dalam penelitian ini adalah ternak kambing jantan Peranakan Etawah yang berumur \pm 12 bulan untuk ditampung semennya dengan menggunakan vagina buatan.

\section{Bahan Pengencer SMD}

Tabel. Komposisi bahan pengencer SMD

\begin{tabular}{lc}
\hline \multicolumn{1}{c}{ Bahan } & Jumlah (\%) \\
\hline Skim Milk (g) & 10 \\
Glucose (g) & 1 \\
Peniciline (IU) & $100.000 \mathrm{IU} / 100 \mathrm{ml}$ \\
Streptomisin (ml) & $0,1 \mathrm{~g} / 100$ \\
Kuning telur (v) & 5 \\
Distilled Water (v) & 80 \\
\hline
\end{tabular}

\section{Peralatan}

Peralatan yang digunakan dalam penelitian ini adalah vagina buatan, tabung Erlenmeyer, eppendorf, tabung reaksi, sterear, neraca/timbangan, rotary evaporator, grinder, kertas saring, dan mikroskop.

\section{Prosedur Kerja}

\section{Persiapan Bahan}

Biji dari limbah edamame dibersihkan kemudian dikeringkan dengan cara diangin-anginkan lalu dihaluskan sampai berupa serbuk.

\section{Ekstraksi Limbah Edamame}

Serbuk limbah edamame dimaserasi dengan etanol $96 \%$ sebanyak $1 / 2$ sampai sama dengan berat serbuk biji limbah edamame dan dibiarkan selama 2 jam. Perkolasi: bagian bawah perkolator diberi kapas dan di atasnya kertas saring. Serbuk edamame yang sudah dibasahi ditambah cairan penyari (etanol) sampai $3 / 4$ perkolator, dibiarkan termaserasi selama semalam. Setelah itu hasil perkolasi dikerluarkan melalui kran dan ditampung. Perkolat yang diperoleh dipekatkan dengan penguap putar hingga menjadi ekstrak kental. 
Nurkholis, Minimalisasi Kerusakan Spermatozoa Kambing Peranakan Etawah Akibat Radikal Bebas Selama Periode Cryopreservation Dengan Penambahan A Tokoferol Dari Ekstrak Limbah Edamame Dalam Skim Milk Dilution

\section{Uji Aktivitas Antioksidan}

Pengujian antioksidan dilakukan dengan menggunakan metode DPPH. Metode DPPH didasarkan kepada kemampuan antioksidan untuk menghambat radikal bebas dengan mendonorkan atom hydrogen. Metode ini menggunakan control posotif sebagai pembanding untuk mengetahui aktivitas antioksidan sampel. Control positif ini dapat berupa tokoferol, BHT, dan Vitamin C. uji aktivitas antioksidan dengan metode DPPH menggunakan 1,1difenil-2-pikrilhidra-zil sebagai radikal bebas. Prinsipnya adalah reaksi penangkapan hydrogen oleh DPPH dari senyawa antiolsidan.

Tata Laksana Pemeliharaan kambing Peranakan

\section{Etawah}

Kambing Peranakan Etawah jantan yang digunakan dalam penelitian ini berjumlah 2 ekor dengan umur \pm 12 bulan. Pemeliharaan dilakukan dengan system intensif dimana segala kebutuhan ternak sepenuhnya dipenuhi oleh pemelihara. Kambing PE jantan dipelihara dalam kandang individu, hal ini bertujuan untuk mempermudah pengawasan baik akan kebutuhan nutrisi maupun kesehatan, selain itu juga untuk menghindari adanya perkelahian antar kambing PE jantan. Sebelum pelaksanaan penelitian tahap 2 dimulai terlebih dahulu kambing PE jantan tersebut dilatih untuk diambil semennya dengan menggunakan vagina buatan, sehingga pada saat pelaksanaan penelitian kambing PE jantan sudah bisa untuk diambil semennya. Jenis pakan yang diberikan pada kambing PE jantan terdiri atas hijauan dan pakan penguat. Untuk kambing PE jantan dewasa pakan kasar/hijauan diberikan sejumlah $10 \mathrm{~kg}$ sedangkan pakan penguat 0,50 kg (Murtidjo, 2005).

Prosedur pembuatan pengencer semen kambing PE

- Penimbangan bahan pengencer (skim milk dan glukosa)

- Memasukkan bahan tersebut dalam Erlenmeyer kemudian ditambahkan dengan aquadest

- Bahan pengencer + aquadest dipanaskan selama 10 menit

- Sebelum ditambahkan kuning telur dan antibiotic, bahan pengencer + aquadest didinginkan hingga mencapai suhu $<40^{\circ} \mathrm{C}$

- Campuran bahan pengencer + aquadest + kuning telur + antibiotic didiamkan selama 3 hari, sampai terbentuk endapan padat

- Pisahkan cairan dengan padatan

Penambahan ekstrak limbah edamame dalam pengencer semen kambing $\mathbf{P E}$
Pada penelitian tahap kedua ini terdapat 5 perlakuan (P) dan dengan 4 ulangan. 4 kelompok waktu koleksi digunakan sebagai ulangan, yaitu koleksi minggu pertama, koleksi minggu kedua, koleksi minggu ketiga dan koleksi minggu keempat.

Perlakuan dosis $\alpha$ tokoferol adalah:
1. $\mathrm{P} 0=$ Pengencer SMD telur tanpa ekstrak edamame

2. $\mathrm{P} 1=$ Pengencer $\mathrm{SMD}+0,1$ gram ekstrak edamame per $100 \mathrm{ml}$

3. $\mathrm{P} 2=$ Pengencer $\mathrm{SMD}+0,2$ gram ekstrak edamame per $100 \mathrm{ml}$

4. $\mathrm{P} 3=$ Pengencer $\mathrm{SMD}+0,3$ gram ekstrak edamame per $100 \mathrm{ml}$

5. $\mathrm{P} 4=$ Pengencer $\mathrm{SMD}+0,4$ gram ekstrak edamame per $100 \mathrm{ml}$

Alawiyah dan Hartono (2006) menyatakan bahwa penambahan vitamin E dalam pengencer SKT pada pembekuan sperma kambing memberikan hasil terbaik pada $0.4 \mathrm{~g} / 100 \mathrm{ml}$ pengencer.

\section{Parameter yang Diamati}

Parameter yang diamati pada penelitian ini adalah kualitas semen kambing PE selama proses preservasi/pengawetan. Kualitas semen yang diamati meliputi:

a. Kuantitas dan kualitas semen segar: warna, volume, kekentalan, $\mathrm{pH}$, konsentrasi, persentase motilitas, viabilitas, dan abnormalitas.

b. Kuantitas spermatozoa setelah diencerkan: persentase motilitas individu, viabilitas, dan abnormalitas.

\section{Pengamatan kuantitas dan kualitas semen kambing}

\section{PE pada suhu kamar}

Semen yang telah diencerkan dimasukkan dalam tabung reaksi atau eppendorf sekitar $0,5 \mathrm{ml}$ dan disimpan pada suhu kamar. Pengamatan terhadap kuantitas dan kualitas semen dilakukan pada jam 0,2 , 4,6 , dan 8

\footnotetext{
Pengamatan kuantitas dan kualitas semen kambing PE pada suhu dingin

Semen yang telah diencerkan dimasukkan dalam tabung reaksi atau eppendorf sekitar $0,5 \mathrm{ml}$ kemudian disimpan pada suhu dingin $\left(3-5^{\circ} \mathrm{C}\right)$. Pengamatan terhadap kuantitas dan kualitas semen dilakukan pada jam 0, 12, 24, dan 48.
} 


\section{Rancangan Penelitian}

\section{Analisa Rancangan Acak Lengkap (RAL)}

Rancangan penelitian yang digunakan adalah RAL (Rancangan Acak Lengkap), kemudian dilanjutkan dengan analisa sidik ragam yang merupakan prosedur penghitungan besaran statistik $\mathrm{F}$ dengan bantuan tabel. Besaran $\mathrm{F}$ berguna untuk menguji ada tidaknya perbedaan pengaruh perlakuan yang diberikan terhadap respons bahan percobaan. Jika hasil perhitungan dari setiap parameter memperlihatkan perbedaan yang nyata atau sangat nyata, maka pengujian akan dilanjutkan dengan uji lanjutan. Uji lanjutan dapat dilakukan dengan beberapa metode yaitu uji BNJ, uji BNT dan uji JND. Berikut adalah tabel Anova menurut Hanafiah (2003).

\section{HASIL DAN PEMBAHASAN}

\section{Aktivitas Antioksidan Edamame}

Pengujian aktivitas antioksidan pada sampel ekstrak edamame dilakukan dengan menggunakan metode Dot-Blot. Metode Dot-Blot adalah suatu metode untuk menentukan potensi antioksidan secara visual sebelum dilakukan pengujian lebih lanjut pada ekstrak. Aktivitas antioksidan pada suatu sampel ditentukan dengan munculnya warna putih pada lempeng silica setelah disemprot dengan larutan DPPH. Pengujian potensi antioksidan dengan metode Dot-Blot dilakukan sebagai pengujian semi kuantitatif secara visual (Huang et al., 2004).

Hasil pengujian aktivitas antioksidan pada sampel ekstrak edamame menunjukan hasil positif (mengandung antioksidan). Hal ini ditunjukan dengan adanya noda putih pada lempeng silica yang sebelumnya sudah ditotolkan larutan uji (ekstrak edamame) dan disemprot DPPH dengan konsentrasi $0,1 \mathrm{mM}$. Noda putih pada lempeng silica menunjukkan kapasitas penangkapan radikal bebas dari ekstrak edamame. Huang et al., (2004) menyatakan bahwa, penangkapan radikal bebas oleh bahan uji/sampel merupakan suatu peristiwa yang memperlihatkan proses penghambatan oksidasi dengan mendonorkan atom $\mathrm{H}$.

Edamame merupakan varietas tanaman kedelai, dimana kedelai merupakan jenis tanaman yang kaya akan sumber antioksidan. Menurut Aak (1989) dan De Meija (2009), kedelai adalah salah satu tanaman yang kaya akan kandungan senyawa antioksidan diantaranya adalah vitamin E dan senyawa flavonoid golongan isoflavon, genestein, dan daidzein. Antioksidan merupakan zat yang mampu memperlambat atau mencegah proses oksidasi.
Antioksidan berperan dalam membantu melindungi struktur sel terutama membrane sel dari kerusakan akibat adanya raadikal bebas (Wijaya, 1996), sedangkan menurut Anonimus (2011), prinsip kerja dari antioksidan dapat dibagi menjdai tiga yaitu, 1) primer: mencegah pembentukan radikal bebas baru dengan memutus reaksi berantai dan mengubahnya menjadi produk yang lebih stabil, 2) sekunder: menangkap senyawa radikal dan mencegah terjadinya reaksi berantai, dan 3) tersier: memperbaiki kerusakan sel dan jaringan yang disebabkan oleh radikal bebas.

\section{Karakteristik Semen Kambing Peranakan Etawah}

Pengamatan karakteristik semen kambing

Peranakan Etawah dilakukan dengan mengunakan dua prosedur, yaitu: pengamatan secara makroskopis dan mikroskopis. Pengamatan karakteristik semen kambing Peranakan Etawah secara makroskopis (pengamatan visual tanpa menggunakan alat bantu) meliputi, volume, kekentalan, dan $\mathrm{pH}$ semen. Sedangkan, pengamatan karakteristik semen kambing Peranakan Etawah secara mikroskopis (menggunakan alat bantu berupa mikroskop) meliputi, konsentrasi, viabilitas, motilitas, dan abnormalitas.

Karakteristik umum semen kambing Peranakan Etawah dapat dilihat pada tabel di bawah ini.

Tabel 2. Karakteristik semen kambing Peranakan Etawah

\begin{tabular}{ll}
\hline \multicolumn{1}{c}{ Variabel } & \multicolumn{1}{c}{ Hasil Pengamatan } \\
\hline Warna & Putih - Krem \\
Volume (ml) & $0,78 \pm 0,11$ \\
Kekentalan & Agak Kental - Kental \\
$\mathrm{pH}$ & 7 \\
Konsentrasi $\left(10^{7} / \mathrm{ml}\right)$ & $286,3 \pm 113,7$ \\
Motilitas Individu $(\%)$ & $70,63 \pm 3,20$ \\
Viabilitas $(\%)$ & $82,49 \pm 4,84$ \\
Abnormalitas $(\%)$ & $7,39 \pm 1,23$ \\
\hline
\end{tabular}

Warna semen kambing Peranakan Etawah hasil penampungan bervariatif yakni putih dan krem, hal ini sesuai dengan pendapat Jiabi, et al., (2001) yang menyatakan bahwa warna semen kambing cukup bervariatif yaitu dari keabu - abuan, putih susu, kuning susu atau krem. Variasi warna semen bisa terjadi antar pejantan dan pada pejantan yang sama dari semen hasil ejakulasi yang berbeda. Warna dapat dijadikan sebagai paremeter bagi kualitas semen, dimana warna semen yang menyimpang dapat diartikan bahwa semen tersebut telah terkontaminasi dengan benda asing. Semen berwarna merah 
Nurkholis, Minimalisasi Kerusakan Spermatozoa Kambing Peranakan Etawah Akibat Radikal Bebas Selama Periode Cryopreservation Dengan Penambahan A Tokoferol Dari Ekstrak Limbah Edamame Dalam Skim Milk Dilution

menandakan adanya darah yang berasal dari saluran kelamin, warna hijau kekuningan apabila dalam semen tersebut terdapat kuman dari spesies Pseudomonas aeruginosa dan juga didapati gumpalan - gumpalan yang menunjukkan adanya nanah pada semen yang umumnya berasal dari kelenjar-kelenjar pelengkap (Toelihere, 1993).

Rata - rata volume semen kambing Peranakan Etawah hasil penampungan adalah 0,78 \pm $0,11 \mathrm{ml}$ per ejakulasi. Volume semen yang tertampung dapat langsung terbaca pada tabung penampungan yang berskala. Volume semen kambing normal menurut Haenlein, et. al, (1999) adalah 0,5 - $1 \mathrm{cc}$ per ejakulasi. Toelihere (1993) menambahkan bahwa, besarnya volume semen yang diejakulasikan tergantung pada bangsa, umur, ukuran badan, nilai nutrisi, dan frekuensi penampungan. Volume rendah tidak akan merugikan sebab tidak terdapat hubungan dengan fertilitas atau sterilitas pejantan.

Kekentalan atau konsistensi semen kambing Peranakan Etawah dapat digolongkan menjadi agak kental dan kental. Tingkat kekentalan semen dapat digunakan untuk penafsiran konsentrasi spermatozoa dalam satu ml semen. Hafez (2000), menyatakan bahwa tingkat kekentalan semen memiliki korelasi positif dengan jumlah spermatozoa, hal ini ditunjukkan dengan semen yang encer akan memiliki konsentrasi yang rendah. pH semen kambing Peranakan Etawah hasil penampungan adalah 7 . Winarto dan Nurul (2008), menyatakan bahwa $\mathrm{pH}$ semen kambing Peranakan Etawah adalah 7,00 $\pm 0,00$.

Rata - rata konsentrasi dan motilitas individu spermatozoa kambing Peranakan Etawah masing masing adalah $286,3 \pm 113,7 \times 10^{7} / \mathrm{ml}$ dan $70,63 \pm$ $3,20 \%$. Secara umum konsentrasi spermatozoa kambing per ejakulasi dapat mencapai $2,5 \times 10^{9} / \mathrm{ml}$ sampai $5 \times 10^{9} / \mathrm{ml} \mathrm{Ax}$, et al., (2000). Motilitas individu spermatozoa yang baik adalah pergerakan progressive, syarat minimal motilitas individu spermatozoa untuk bisa diproses lebih lanjut (diencerkan dan dibekukan) yaitu $70 \%$ (grade 2). Penggabungan konsentrasi spermatozoa dengan volume semen dan presentase motil memberikan jumlah spermatozoa motil per ejakulasi (Hafez, 2000).

Pengamatan viabilitas spermatozoa dapat dilakukan secara bersamaan dengan pengamatan persentase abnormalitas spermatozoa. Rata - rata persentase viabilitas dan abnormalitas spermatozoa adalah $82,49 \pm 4,84 \%$ dan $7,39 \pm 1,23 \%$. Viabilitas spermatozoa tidak dapat digunakan sebagai parameter dalam penentuan tingkat kesuburan pejantan. Toelihere (2003), menyatakan bahwa rata - rata $20 \%$ spermatozoa yang mati ditemukan dalam contoh semen relatif hanya sedikit korelasinya dengan kesuburan pejantan. Persentase abnormalitas spermatozoa hasil pengamatan tergolong normal, kelainan morfologi pada spermatozoa di bawah $20 \%$ tergolong normal sedangkan apabila di atas $20 \%$ akan berakibat pada penurunan fertilitas spermatozoa (Ax, et al., 2000).

\section{Kualitas Semen Setelah Proses Pengenceran}

Hasil pengamatan kualitas semen kambing Peranakan Etawah setelah pengenceran dapat dilihat pada tabel 3 .

Tabel 3. Kualitas semen kambing Peranakan Etawa setelah proses pengenceran.

\begin{tabular}{ll}
\hline \multicolumn{1}{c}{ Variabel } & \multicolumn{1}{c}{ Hasil Pengamatan } \\
\hline Motilitas individu (\%) & $65,63 \pm 3,20$ \\
Viabilitas (\%) & $79,56 \pm 6,27$ \\
Abnormalitas (\%) & $7,70 \pm 1,22$ \\
\hline
\end{tabular}

Hasil pengamatan kualitas semen kambing Peranakan Etawah setelah pengenceran secara statistik mengalami penurunan, terutama persentase motilitas individu. Hal ini diduga adanya partikel - partikel bahan pengencer yang menghalangi atau menghambat pergerakan dari spermatozoa. Toelihere (2003) menyatakan bahwa, butir - butir lemak yang terdapat pada bahan pengencer susu skim akan dapat menghambat pergerakan dari spermatozoa.

\section{Kualitas Semen pada Penyimpanan Suhu Kamar}

\section{Motilitas Individu}

Persentase motilitas spermatozoa individu pada umumnya digunakan sebagai pedoman dalam penentuan daya reproduksi ternak jantan. Persentase motilitas di bawah $40 \%$ menunjukkan nilai semen yang kurang baik dan sering berhubungan dengan infertilitas. Kebanyakan pejantan yang fertile mempunyai $50 \%$ sampai $80 \%$ spermatozoa yang motil aktif progresif (Hafez, 2000). Hasil analisis ragam menunjukan bahwa penambahan antioksidan dari ekstrak edamame tidak berpengaruh nyata $(\mathrm{P}>$ $0,05)$ terhadap lama simpan semen pada suhu kamar, akan tetapi secara statistik semen yang ditambahkan ekstrak memiliki persentase motilitas yang lebih baik dibandingkan dengan kontrol. Rata - rata persentase motilitas spermatozoa tertera pada tabel 4 .

Tabel 4. Rata - rata motilitas spermatozoa kambing Peranakan Etawah

\begin{tabular}{cccccc}
\hline \multirow{2}{*}{ Perlakuan } & \multicolumn{5}{c}{ Motilitas (\%) } \\
\cline { 2 - 6 } & 0 (jam) & 2 (jam) & 4 (jam) & 6 (jam) & 8 (jam) \\
\hline P0 & 65 & 55 & 51,25 & 46,25 & 42,5 \\
P1 & 65 & 62,5 & 60 & 55 & 51,25
\end{tabular}


Jurnal Ilmiah INOVASI, Vol.12 No.3, Hal.145-153, Mei-Agustus 2013, ISSN 1411-5549

\begin{tabular}{lccccc} 
P2 & 65 & 61,25 & 58,75 & 56,25 & 53,75 \\
P3 & 66,25 & 66,25 & 62,5 & 58,75 & 53,75 \\
P4 & 66,25 & 66,25 & 65 & 61,25 & 60 \\
\hline
\end{tabular}

\section{Abnormalitas Spermatozoa}

Hasil analisis sidik ragam memperlihatkan tidak adanya pengaruh nyata $(\mathrm{P}>0,05)$ pemberian ekstrak edamame pada tiap perlakuan terhadap tingkat abnormalitas spermatozoa selama proses penyimpanan. Rata - rata tingkat abnormalitas spermatozoa selama proses penyimpanan tersaji pada tabel 5.

Tabel 5. Rata - rata tingkat abnormalitas spermatozoa selama penyimpanan

\begin{tabular}{cccccc}
\hline & \multicolumn{5}{c}{ Abnormalitas (\%) } \\
\cline { 2 - 6 } Perlakuan & 0 & 2 & 4 & 6 & 8 \\
& $(\mathrm{jam})$ & $(\mathrm{jam})$ & $(\mathrm{jam})$ & $(\mathrm{jam})$ & $(\mathrm{jam})$ \\
\hline P0 & 8,45 & 10,88 & 14,45 & 17,83 & 20,13 \\
P1 & 8,45 & 9 & 9,98 & 12,3 & 14,43 \\
P2 & 8,45 & 8,88 & 9,18 & 10,08 & 10,88 \\
P3 & 6,95 & 7,18 & 7,83 & 8,13 & 8,88 \\
P4 & 6,95 & 7 & 7,2 & 7,68 & 7,87 \\
\hline
\end{tabular}

\section{Viabilitas Spermatozoa}

Viabilitas atau persentase spermatozoa hidup dievaluasi dengan pewarnaan eosin nigrosin. Pada waktu semen dicampur dengan zat warna, sel - sel sperma yang hidup tidak atau sedikit sekali menghisap warna sedangkan sel - sel yang mati akan mengambil warna karena permeabilitas dinding sel meninggi sewaktu mati. Zat warna eosin akan mewarnai spermatozoa yang mati menjadi merah, sedangkan sperma yang hidup tidak berwarna (Hafez, 2000). Hasil analisis sidik ragam menunjukkan pemberian ekstrak edamame tidak berpengaruh nyata $(\mathrm{P}>0,05)$ terhadap persentase viabilitas spermatozoa selama Tabel 7. Rata - rata motilitas kambing Peranakan Etawah penyimpanan pada suhu kamar. Rata - rata persentase viabilitas spermatozoa dapat dilihat pada tabel 6 .

Tabel 6. Rata - rata persentase viabilitas spermatozoa

\begin{tabular}{cccccc}
\hline & \multicolumn{5}{c}{ Viabilitas (\%) } \\
\cline { 2 - 6 } Perlakuan & 0 & 2 & 4 & 6 & 8 \\
& $($ jam) & (jam) & (jam) & (jam) & (jam) \\
\hline P0 & 78,53 & 74,08 & 69,05 & 64,7 & 60,7 \\
P1 & 78,53 & 75,75 & 72,15 & 65,08 & 62,1 \\
P2 & 78,53 & 76,28 & 73,7 & 67,5 & 63,98 \\
P3 & 80,6 & 78,58 & 75,13 & 72,43 & 68,08 \\
P4 & 80,6 & 59,43 & 76,48 & 74,75 & 72,1 \\
\hline
\end{tabular}

Tidak berpengaruhnya ekstrak edamame dalam mempertahankan kualitas semen (motilitas, abnormalitas, dan viabilitas) selama proses penyimpanan pada suhu kamar diduga karena peluang kontak antara semen dengan udara cukup besar. Menurut Hammerstedt (1993), reaksi samping metabolisme aerob akan menghasilkan anion superoksida yang dapat menyebabkan kerusakan sel apabila bereaksi dengan oksigen. Sehingga, antioksidan yang ada pada ekstrak edamame kurang dapat berfungsi sebagai superoksida yang dapat menghilangkan anion superoksida dan meminimalkan kerusakan peroksidatif.

\section{Kualitas Semen pada Penyimpanan Suhu Dingin}

\section{Motilitas Spermatozoa}

Hasil analisis sidik ragam, penambahan ekstrak limbah edamame pada pengencer tidak memberikan pengaruh nyata $(\mathrm{P}>0,05)$ terhadap persentase motilitas spermatozoa individu selama penyimpanan suhu dinging $\left(3-5^{\circ} \mathrm{C}\right)$. Penelitian yang sama telah dilakukan oleh Wiendarti dkk (1999), dari hasil penelitiannya dilaporkan bahwa pemberian antioksidan pada bahan pengencer tidak memberikan peranan yang nyata terhadap motilitas spermatozoa yang disimpan dalam suhu $3-5{ }^{\circ} \mathrm{C}$. Rata - rata motilitas individu spermatozoa kambing Peranakan Etawah disajikan pada tabel 7. 
Nurkholis, Minimalisasi Kerusakan Spermatozoa Kambing Peranakan Etawah Akibat Radikal Bebas Selama Periode Cryopreservation Dengan Penambahan A Tokoferol Dari Ekstrak Limbah Edamame Dalam Skim Milk Dilution

\begin{tabular}{ccccc}
\hline Perlakuan & \multicolumn{3}{c}{ Motilitas (\%) } \\
\cline { 2 - 5 } & 0 (jam) & 12 (jam) & 24 (jam) & 48 (jam) \\
\hline P0 & 65 & 61,25 & 48,75 & 46,25 \\
P1 & 65 & 63,75 & 61,25 & 56,25 \\
P2 & 65 & 65 & 61,25 & 60 \\
P3 & 66,25 & 66,25 & 65 & 61,25 \\
P4 & 66,25 & 66,25 & 66,25 & 63,75 \\
\hline
\end{tabular}

Berdasarkan rata - rata yang tertera pada tabel, pemberian ekstrak edamame dapat memberikan sedikit fungsi bagi spermatozoa dalam mempertahankan motilitas selama proses penyimpanan. Ekstrak edamame mengandung antioksidan, dimana antioksidan berfungsi dalam pencegahan timbulnya kerusakan membrane sel akibat peristiwa peroksidatif (Hammerstedt, 1993).

Tabel 8. Rata - rata tingkat abnormalitas semen kambing

\begin{tabular}{ccccc}
\hline & \multicolumn{4}{c}{ Abnormalitas (\%) } \\
\cline { 2 - 5 } Perlakuan & 0 & 12 & 24 & 48 \\
& (jam) & (jam) & (jam) & (jam) \\
\hline P0 & 8,45 & 8,65 & 8,83 & 9,3 \\
P1 & 8,45 & 8,67 & 8,97 & 9,17 \\
P2 & 8,45 & 8,6 & 8,8 & 8,97 \\
P3 & 6,95 & 7,15 & 7,25 & 7,52 \\
P4 & 6,95 & 7 & 7,1 & 7,5
\end{tabular}

\footnotetext{
Abnormalitas Spermatozoa

Tingkat abnormalitas spermatozoa kambing Peranakan Etawah setelah

dilakukan penyimpanan berkisar $6,95 \%$ sampai 9,3\%. Persentase abnormalitas sepermatozoa kambing Peranakan Etawah hasil penyimpanan pada suhu dingin $\left(3-5{ }^{\circ} \mathrm{C}\right)$ tergolong rendah/kecil.

Menurut Hafez (2000), spermatozoa dengan tingkat abnormalitas di bawah $20 \%$ cukup layak untuk digunakan inseminasi buatan. Untuk mengetahui adanya pengaruh penambahan ekstrak dalam pengencer maka dilakukan analisis sidik ragam. Hasil analisis sidik ragam menunjukkan penambahan ekstrak edamame dalam pengencer berpengaruh nyata $(\mathrm{P}<$ 0,05) terhadap tingkat abnormalitas spermatozoa selama penyimpanan, berarti dengan penambahan antioksidan dari ekstrak edamame dapat mempertahankan membrane plasma dari kerusakan sehingga jumlah spermatozoa abnormal tetap kecil.
}

Uji beda rerata pengaruh perlakuan diperlukan untuk mengetahui perlakuan yang memberikan pengaruh terbaik pada pertambahan bobot badan ayam buras betina. Uji beda rerata yang digunakan adalah BNT. Hasil uji BNT ditunjukkan pada tabel 9.

Tabel 9. Hasil uji BNT pengaruh pemberian ekstrak edamame terhadap tingkat abnormalitas spermatozoa kambing Pernakan Etawah

\begin{tabular}{cc}
\hline Perlakuan & Notasi \\
\hline P0 & $\mathrm{a}$ \\
P1 & $\mathrm{a}$ \\
P2 & $\mathrm{a}$ \\
P3 & $\mathrm{b}$ \\
P4 & $\mathrm{b}$ \\
\hline
\end{tabular}

Dari tabel 9 dapat dijelaskan $\mathrm{P} 4$, berbeda tidak nyata dengan P3, dan berbeda nyata dengan P0, P1 serta P2. Jadi, kesimpulannya adalah P4 (dosis 0,4 gr penambahan ekstrak edamame) memberikan pengaruh terbaik dalam mempertahankan tingkat abnormalitas spermatozoa selama penyimpanan. Menurut Alawiyah dan Hartono (2006), semakin banyak antioksidan yang ditambahkan maka semakin banyak atom hydrogen yang dilepaskan sehingga lebih mampu untuk mencegah terjadinya peroksida lipid dengan cara menstransfer atom hidrogennya ke radikal peroksil.

\section{Viabilitas Spermatozoa}

Hasil statistik perhitungan rerata viabilitas spermatozoa kambing Peranakan Etawah dapat dilihat pada tabel 10 .

Tabel 10 menunjukkan hasil rataan pengamatan spermatozoa hidup, nilai tertinggi dihasilkan oleh bahan pengencer yang diberi ekstrak edamame yang mengandung antioksidan, sedangkan persentase spermatozoa hidup terendah dihasilkan oleh bahan pengencer tanpa penambahan ekstrak edamame. Hasil analisis sidik ragam, penambahan ekstrak edamame pada bahan pengencer tidak meberikan pengaruh nyata $(\mathrm{P}>0,05)$ terhadap viabilitas spermatozoa. Tingkat viabilitas spermatozoa tergantung pada keutuhan dari 
membrane plasma (Toelihere, 2003). Antioksidan yang ditambahkan pada bahan pengencer tidak berpengaruh terhadap keutuhan membrane plasma semen (Wiendarti dkk., 1999)

Table 10. rata - rata tingkat viabilitas spermatozoa kambing Peranakan Etawah

\begin{tabular}{ccccc}
\hline \multirow{2}{*}{ Perlakuan } & \multicolumn{4}{c}{ Viabilitas (\%) } \\
\cline { 2 - 5 } & 0 (jam) & 12 (jam) & 24 (jam) & 48 (jam) \\
\hline P0 & 78,53 & 77,15 & 71,25 & 67,4 \\
P1 & 78,53 & 78,17 & 75,35 & 71,1 \\
P2 & 78,53 & 78,05 & 77,2 & 74,27 \\
P3 & 80,6 & 78,25 & 76,5 & 76,25 \\
P4 & 80,6 & 79,45 & 78,17 & 77,47 \\
\hline
\end{tabular}

\section{KESIMPULAN DAN SARAN}

\section{KESIMPULAN}

1. Penambahan ekstrak edamame tidak memberikan pengaruh nyata $(\mathrm{P}>0,05)$ dalam mempertahankan kualitas (motilitas, abnormalitas, dan viabilitas) semen kambing Peranakan Etawah selama penyimpanan pada suhu kamar dan suhu dingin (3 $-5^{\circ} \mathrm{C}$ ).

2. Penambahan ekstrak edamame memberikan pengaruh nyata $(\mathrm{P}<0,05)$ terhadap persentase abnormalitas spermatozoa pada penyimpanan suhu dingin.

3. Penambahan ekstrak edamame dengan dosis 0,4 $\mathrm{g} / 100 \mathrm{ml}$ memberikan hasil rerata yang lebih tinggi dibandingkan dengan dosis yang lebih rendah.

\section{SARAN}

Penambahan ekstrak edamame dengan dosis $0,4 \mathrm{~g} / 100$ $\mathrm{ml}$ dalam pengencer semen dapat dilakukan dengan tujuan untuk mempertahankan kualitas spermatozoa selama penyimpanan.

\section{DAFTAR PUSTAKA}

Anonimus, 2010.2 Vitamin E. file://localhost/H:/vitamin $\% 20 \mathrm{E} /$ Radikal $\% 20$ bebas\%20-

\%20Wikipedia\%20bahasa\%20Indonesia,\%20 ensiklopedia\%20bebas.mht). Diunduh tanggal 7 februari 2011

2011. Antioksidan. file://localhost/H:/vitamin\%20E/Radikal\%20 bebas\%20\%20Wikipedia\%20bahasa\%20Indonesia,\%20 ensiklopedia\%20bebas.mht).

Alawiyah, D. dan M. Hartono. 2006. Pengaruh Penambahan Vitamin E dalam Bahan Pengencer Sitrat Kuning Telur terhadap Kualitas Semen Beku Kambing Boer. Jurnal Pengembangan Peternakan Tropis:31 (1): 8—14

Asih I. A. R. A., 2009. Isolasi dan Identifikasi Senyawa Isoflavon dar Kacang Kedelai. Jurnal Kimia. 3 (1). Januari 2009 : 33-40

Beconi, M.T., C.R. Frarcia, N.G. Mora, dan M.A. Affranchino. 1993. "Effect of natural antioxidant on frozen bovine semen preservation". Theriogenology 40: $841-851$

Chen J, Okada T , Muramoto K, Suetsuna K, Yang S. 2003. Identification of angiotensin Iconverting enzyme inhibitory peptides 
Nurkholis, Minimalisasi Kerusakan Spermatozoa Kambing Peranakan Etawah Akibat Radikal Bebas Selama Periode Cryopreservation Dengan Penambahan A Tokoferol Dari Ekstrak Limbah Edamame Dalam Skim Milk Dilution

derived from the peptic digest of soybean protein. J. Food Biochemistry.26(6):543-554.

Davendra C., dan Burns M., 1994. Produksi Kambing di daerah Tropis. Penerbit ITB. Bandung.

De Meija, E. 2009. Potential of Bioactive Peptides in Prevention of Chronic Disease. United Soybean Board. USA.

Edwards, H.M. 1985. Effects of Different Soybean Meals on the Incidence of Tibial Dyschondroplasia in the Chicken. J.Nutrition. 115: 1005-1015.

Feradis, 2010. Penggunaan Vitamin E dan BHT dalam Pengencer Semen Beku Domba. Jurnal Peternakan. Vol 7. No. 1 Februari 2010.

Gibbs BF, Zougman A, Masse R, Mulligan C. 2004. Production and characterization of bioactive peptides from soy hydrolysate and soyfermented foods. Food Research International 37(2):123-131.

Hammerstedt, R. H. 1993. Maintenance of Bioenergic Balance in Sperm and Prevention of Lipid Peroxydation. J. Reprod. Fertil.

Hanafiah K. A. 2003. Rancangan Percobaan, Teori dan Aplikasi. Fakultas Pertanian Universitas Sriwijaya. Palembang. PT. RajaGrafindo Persada. Jakarta.

Hartono M., 2008. Optimalisasi Pembekuan Vitamin E dalam Pengencer Sitrat Kuning Telur untuk Mepertahankan Kualitas Semen Kambing Boer. Received Vovember 23. 2008; Accepted January 2008.

Mayes, P.A., 1995. Struktur dan Fungsi Vitamin yang Larut dalam Lemak. Dalam D. H. Ronardy dan J. Oswari (Eds). Biokimia Harper. Penerbit Buku Kedokteran, EGC. Jakarta.
Mc Mahon, S., 2009. Functional Feed and Feeding Towards Better Animal Production. Proceeding International Workshop on Animal Health. University of Guelph. Canada

Murtidjo B. A., 2005. Memelihara Kambing Sebagai ternak Potong dan Perah. Penerbit Kanisius. Yogyakarta.

Nuryadi, 2000. Dasar - Dasar Reproduksi Ternak. Universitas Brawijaya. Fakultas Peternakan. NES-PRESS. Malang.

Ososki A. L., and Edward J. K., 2003. Phytoestrogens: a Review of the Present State of Research. Phytotherapy Research. 17,845-869(2003). www.interscience.wiley.com. DOI: 10. 1002/ptr.1364.

Riedl K. M., Jae H. L., Marjory R., Steven K. S. M., Steven J. S., and Yael V., 2007. Isoflavone Profiles, Phenol Content, and Antioxidant Activity of Soybean Seeds as Influenced by Cultivar and Growing Location in Ohio. Journal of the Science of Food and Agriculture. 87:1197-1206(2007).

Suyadi dan Trinil S., 1992, Pengantar Fisiologi Reproduksi. Program Studi Reproduksi dan Pemuliaan Ternak. LUW-Universitas Brawijaya. Animal Husbandry Project. Malang.

Toelihere M. S., 2003. Fisiologi Reroduksi Pada Ternak. Penerbit Angkasa. Bandung.

Zenichiro K., Herliantien dan Srastina. 2002. Teknologi Prosesing Semen Beku pada Sapi. Penrbit BIB Singosari. Malang. 